\title{
Recurring Displacement, Homemaking and Solidarity amongst Syrian and Palestinian Syrian Refugees in Turkey
}

Nell Gabiam

\begin{abstract}
This article focusses on Al-Nur, a community centre in Istanbul, Turkey, that caters to Syrian and Palestinian Syrian refugees. It is based on five months of fieldwork conducted in the winter and spring of 2017 in Turkey that included participant observation as a volunteer English teacher at Al-Nur. A focus on the philosophy that guides Al-Nur's functioning as a community centre as well as on the stories of displacement of some of its managers and volunteers sheds light on the importance of being able to (re)create home in exile. Such a focus also sheds light on how repeated displacement has shaped Palestinian Syrian refugees' experiences of exile from Syria as well as their interactions with Syrian refugees.
\end{abstract}

Keywords: home, non-governmental organisations, Palestinian Syrian refugees, refugee-refugee solidarity, repeated displacement, Syrian refugees

Turkey is currently hosting over 3.5 million refugees from Syria, the vast majority of whom are self-settled in urban areas (UNHCR 2020). Amongst those displaced to Turkey by the conflict in Syria are Palestinian refugees whose presence in Syria can be traced back to the 1948 Arab-Israeli War. This article examines the concurrent exile of Syrian and Palestinian Syrian refugees in Turkey. ${ }^{1}$ While it gives an overview of Turkish policy towards the two groups, its main goal is to examine this concurrent exile through the prism of everyday life and especially through the notion of home. The analysis focusses on Al-Nur, a community centre in Istanbul catering to Syrian and Palestinian Syrian refugees. ${ }^{2}$ Al-Nur was founded in 2014 by Khaled, a second-generation Palestinian refugee from the Yarmouk camp in Syria. The centre hosts a variety of activities ranging from language courses to guitar lessons and creative 
writing, which are mostly taught by local as well as international volunteers. While its founders, managers and clients value these classes, one aspect of the centre that receives consistent praise is the home-like atmosphere that it provides. Although created by a Palestinian Syrian refugee, Al-Nur caters to all those displaced from Syria rather than specifically to Palestinians displaced from Syria. Thus, it offers an interesting vantage point from which to reflect on relations between Syrians and Palestinian Syrians outside of Syria and to think about commonalities as well as differences in the experiences of exile of both populations.

\section{Methods}

This article is based on five months of fieldwork conducted in the winter and spring of 2017 in Turkey (primarily in the cities of Istanbul and Gaziantep) that included participant observation as a volunteer English teacher at Al-Nur and as a student in several of the classes offered by the centre. During this time, I also interviewed seven members of the centre's staff, the majority of whom were themselves refugees from Syria. Most of them worked at the centre on a volunteer basis and were also students in some of the classes offered by the centre.

The fieldwork I conducted in Turkey in 2017 is part of a broader research project that began in the spring of 2015 and ended in the summer of 2019 and that examines the experiences of secondary exile of Palestinians displaced by the war in Syria. During this period, I travelled to Lebanon, Jordan, Turkey, the United Arab Emirates, France, Germany and Sweden, and conducted 89 interviews with Palestinians displaced by the war in Syria as well as 38 interviews with individuals and humanitarian organisations involved in the provision of aid or other forms of support to refugees displaced by the war in Syria. Extended periods of time were spent in France ( 7 months), Germany (3 months) and Turkey (6 months). Over the course of my entire fieldwork in Turkey, I conducted a total of 22 interviews with Palestinians displaced by the war in Syria and a total of 24 interviews with staff of humanitarian organisations or volunteers assisting refugees displaced by the war in Syria. Almost all of my interviews with Palestinians displaced by the war in Syria were conducted in Arabic. Interviews with volunteers or staff of humanitarian organisations assisting refugees from Syria in different host states were conducted in either Arabic, English or French. With regard to Al-Nur, all of my interviews with the staff of the organisation were conducted in English, except for one in Arabic.

Al-Nur's emphasis on being home-like had implications for the scope of my fieldwork. While I was free to conduct participant observation, I was asked by the centre's managers to refrain from interviewing (non-staff) refugees enrolled in classes at the centre. I was also asked not to take pictures of the 
centre's classes or activities. Al-Nur's managers generally saw journalists and researchers as having a potentially destabilising effect on the intimate, homelike atmosphere they strove to create for refugees who frequented the centre. I had been given special permission to conduct fieldwork in Al-Nur by Khaled, the centre's director, whom I had met about 11 years earlier while completing doctoral research in Syria.

The first part of the article examines the current situation of Syrian and Palestinian Syrian refugees in Turkey, and reflects on the importance of home as a concept through which to understand the experiences and aspirations of refugees and other migrants. The second part focusses on the philosophy and practices that guide Al-Nur's functioning as a community centre, especially the importance of being able to (re)create home in exile. Building on the conclusions drawn from my fieldwork at Al-Nur, the third part argues that recurring Palestinian displacement within the Middle East and pre-war relations between Syrians and Palestinians in Syria are crucial to understanding the divergences, overlaps and forms of solidarity that characterise concurrent Syrian and Palestinian Syrian exile in Turkey.

\section{Syrian and Palestinian Syrian Refugees in Turkey}

Turkey initially adopted an open-door policy toward Syrian refugees who began to arrive in the country in 2011 (Içduygu et al. 2017). These refugees were referred to as 'guests' by the Turkish government, a term that emanated from the ruling Justice and Development Party (AKP) and that emphasises hospitality justified through the notion of religious fraternity (Içduygu et al. 2017). The status of guest came with no legal rights, but as Syrian exile became prolonged, the Turkish government moved towards providing Syrian refugees with temporary protection. In 2014, the Turkish government passed the Regulation on Temporary Protection, which facilitated Syrian refugees' access to social assistance, health and educational services, and enabled them to apply for work permits (Içduygu and Millet 2016; Leghtas 2019). As part of the 2014 regulation, Syrian refugees receive a temporary protection identification document which validates their temporary protection status and acknowledges their right to stay in Turkey (Içduygu and Millet 2016). ${ }^{3}$

Despite the rights and services to which Syrian refugees are entitled under the 2014 regulation, a majority of them live in an economically vulnerable situation. Few of them have been able to obtain employment permits, given that the process is costly and needs to be initiated by their employer, who is often not willing to do so. A significant number of them are forced to work informally, often in exploitative conditions. In many cases, children are forced to work and forgo school in order to help their families financially (Içduygu 2016; Leghtas 2019). Additionally, since the signing of the 2016 deal between the European Union and Turkey, in which Turkey agreed to restrict migration 
from its shores to Europe, there have been several reports of deportations of Syrian refugees to northern Syria (Leghtas 2019).

The experience of Palestinian Syrians both overlaps with and differs from the above description. From the beginning of the war in Syria, and contrary to their Syrian counterparts, Palestinians were officially required to apply for a visa in order to enter Turkey. ${ }^{4}$ Thus, Palestinians fleeing war from Syria have generally had to enter Turkey clandestinely. While they did not face the threat of deportation once they were in Turkey, they had an ambiguous and precarious legal status and seemed to be falling through the cracks of Turkish relief efforts towards refugees from Syria who were generally understood to be Syrian nationals (Clementi 2015). ${ }^{5}$ According to Palestinian interlocutors, there were many instances of Palestinian Syrian refugees being barred from camps constructed for Syrian refugees even if some were reportedly able to find shelter there. Furthermore, until 2016 Palestinian Syrians in some Turkish provinces were not allowed to enrol in the schools opened by Turkish authorities for refugees from Syria, even if they had a temporary protection ID card. They had to have a visa, which they could only acquire as a result of formal legal travel to Turkey (AGPS and PRC 2018).

Eventually, the Turkish government incorporated a significant number of Palestinian refugees who came from Syria into its temporary protection policy for Syrian refugees, providing them with the same temporary protection ID card and the same rights and services as their Syrian counterparts (AGPS and PRC 2018; Yahia 2020). Overall though, Turkish policy towards Palestinian refugees from Syria remains inconsistent. There are reports, which have been corroborated in my conversation with Palestinian refugees from Syria, that since at least 2016 Palestinians caught crossing the Syria-Turkey border clandestinely have been arrested and jailed for up to a month; they are usually denied the temporary protection ID card upon release and are forced to register and check in every two weeks with the Turkish police (Yahia 2020).

\section{Creating Home despite an Uncertain Future}

Differences in the treatment of Syrians and Palestinian Syrians by Turkish authorities should not blind us to the fact, noted above, that the majority of refugees from Syria (whether Syrian nationals or not) are in an economically vulnerable situation in Turkey and that they are facing tightening Turkish borders. Additionally, by 2017, when I was conducting fieldwork in Istanbul, Turkey was experiencing an economic downturn and the welcoming atmosphere that had initially greeted refugees from Syria had subsided (Daniş and Nazli 2018; Kirişci and Ferris 2015). Refugees from Syria faced hostility and discontent from an increasing number of Turks, especially those in lowincome areas who saw themselves as competing for jobs and resources with these refugees (Daniş and Nazli 2018; Kirişi and Ferris 2015). The Turkish 
government, for its part, was toning down its welcoming rhetoric and increasingly emphasising the issue of Syrian refugee return in public discourse (Içduygu and Sert 2019).

A number of Turkish migration scholars argue that, despite the above turn of events and despite the unwillingness of the government and the Turkish public to admit it, Syrian refugee presence in Turkey which, as of 2020, is in its ninth year, has entered the integration phase (Içduygu and Sert 2019; Daniş and Nazli 2018). Amidst this shift in attitude on the part of the Turkish government and people towards refugees from Syria, non-governmental organisations (NGOs) are playing a crucial role in helping refugees to access the rights provided by the state and to integrate them into society at the local level by creating new social spaces (Sunata and Tosun 2018). Ulaş Sunata and Salih Tosun identify four types of NGOs assisting refugees from the Syrian War who are now in Turkey: NGOs operated by migrants or refugees either locally or internationally, local Turkish NGOs operating on a small scale, international NGOs and professional NGOs that are highly specialised in a particular area and that only operate at the local level.

As the above typology indicates, Al-Nur is not unique in terms of being run primarily by refugees. However, from the perspective of the centre's own staff and leadership, what makes it unique and sets it apart from other officially registered NGOs in Turkey is its home-like atmosphere and the priority it gives to maintaining this atmosphere. This article considers home to be both a material environment and a set of meaningful relationships, recollections and aspirations to be emplaced, successfully or not over space and time' (Boccagni 2017: 14). This understanding of home, which recognises its fluid, shifting and context-specific characteristics, is closely linked to that of homemaking-that is, the ordinary interactions through which individuals try to appropriate and make a variety of places 'meaningful, personal and secure' (Boccagni 2017: 30).

As evidenced in the next section, the related concepts of home and homemaking are particularly useful to understanding Al-Nur as a specific kind of space that caters to Syrian as well as Palestinian Syrian refugees and that can provide us with insight into their concurrent exile in Turkey. These concepts also enable enquiry into the integration of refugees from Syria in Turkey and, linked to it, into refugees' ways of belonging and of negotiating ethnic boundaries (see Boccagni 2017).

\section{'It's like a Home': The Al-Nur Community Centre for Syrian and Palestinian Syrian Refugees}

Al-Nur was created by Khaled, a Palestinian in his mid-50s who is from the urban refugee camp of Yarmouk in Damascus and who works as an Arabic language instructor in Istanbul. ${ }^{6}$ Initially, he was simply trying to find some sort of social space where he and his friends, fellow refugees who had been 
displaced from Syria, could socialise. Khaled's own home in Yarmouk, where he regularly had friends over to spend time together and enjoy his homecooked meals, had been such a space. However, his tiny and cramped apartment in Istanbul was not an adequate substitute.

In 2014, Khaled was able to rent a place with a small kitchen where he and his friends could at least make tea and coffee and have room for a weekly movie night and ping-pong. Little by little, attendance grew, activities multiplied and, in 2015, the space rented by Khaled and his friends to enjoy themselves in Istanbul during their free time was officially registered as an NGO. Since then, Al-Nur has featured a movie night every Friday and has had a ping-pong table. It is now located on the spacious first floor of an Istanbul apartment building with an adjoining courtyard and a basement storage room that also has a library. Beginner, intermediate and advanced-level Turkish and English language classes attract the majority of Al-Nur's loyal clientele. The Turkish instructor had started on a volunteer basis, but because of demand and because of the importance given by the centre to these classes, she was eventually paid for her work. Donations from private individuals living in Turkey, in other parts of the Middle East and in places beyond helped cover the centre's costs. With the exception of the Turkish language class, all the other classes were taught by volunteers. At the time of my fieldwork between February and June 2017, the centre also offered adult French, English, theatre, creative writing in English, and guitar classes, as well as children's arts and science classes on Saturdays. In addition to teaching an adult and a youth English class, I took several classes at the centre and attended the guitar and creative writing classes on a regular basis.

While Al-Nur advertises itself as a community centre for Syrian and Palestinian Syrian refugees, almost all of the refugees who were frequenting it at the time of my fieldwork were Syrians of middle or working-class background. This had not always been the case. Previously, Palestinians made up a significant part of the centre's administration and clientele, but Khaled told me that 'there are no Palestinians left in Istanbul'. Palestinians who came to Istanbul only saw it as a transit point to Europe, he said, explaining that because of their statelessness and treatment by governments in the Middle East, Palestinians 'don't think they can find stability here'. Khaled is right in that most of the Palestinians who crossed Syrian borders into Turkey continued on to Europe. As of May 2020, an estimated 7,000 to 10,000 Palestinian refugees from Syria lived in Turkey, while an estimated 100,000 Palestinians from Syria have reached Europe since the beginning of the Syrian War (AGPS and PRC 2018; Yahia 2020). Most of them presumably took the 'Eastern Mediterranean route', which goes through Turkey (see UNHCR 2015). By 2015, when migration from Syria to Europe peaked, it had become the preferred sea route for refugees from Syria trying to reach Europe. One can conclude from the above numbers that, contrary to their Syrian counterparts, the vast majority of Palestinians who fled to Turkey in the wake of the Syrian War did, in fact, 
consider the country as a transit place on the way to Europe. Nevertheless, as Khaled's own example demonstrates, a few Palestinian Syrians remain in Istanbul and in Turkey more broadly.

By the time I started my fieldwork, Syrians made up most of the centre's volunteer-based administrative structure. Many of these volunteers had started out as clients of the centre and most continued to take classes at the centre. A majority of the classes offered at the centre at the time of my fieldwork were taught by foreigners (including citizens of the United States, Canada, Kazakhstan, South Africa, France, Colombia, Germany, Greece, El Salvador and Russia), but some were taught by Syrian volunteers. A few were taught by Turkish citizens. Khaled's Arabic class, taught twice a week, attracted the few non-refugees (representing a variety of countries) who took classes at the centre. Finally, the centre, in collaboration with an American NGO, was hosting a scholarship programme providing five Syrian young adults with rigorous academic training, aiming to help them get acceptance and a full scholarship at universities in the United States. In light of the Trump travel ban issued in January 2017, the programme abruptly shifted its focus to universities in Canada.

While classes are an important factor in attracting many of Al-Nur's mostly Syrian clientele, the centre's atmosphere is another one. In fact, one could argue that Al-Nur's most important space is not its classrooms but its kitchen. Tea and coffee are always brewing and are often served during classes, and a warm lunch, cooked on the premises, is often available at no cost to anyone who happens to be around, whether student, staff or happenstance visitor. The meals at Al-Nur consist of typical Syrian dishes such as riz wa basale (rice with peas), mouloukhie (a stew made with spinach-like leaves) and makhloube (a dish consisting of rice, eggplant and chicken stacked in layers). Khaled, the centre's director, also does some of the cooking, with falafel (made from scratch) and fatayer (meat or spinach pies) as his specialty dishes. The Saturday morning sessions, focussing on children, always end with a big Syrian meal, which is usually cooked by Khaled. The fridge is continuously packed with labne (a kind of yogurt), olives and bread, which are sometimes served as a morning or afternoon snack and are shared amongst whoever happens to be in the centre at the time. 'It's not just a centre or an NGO', I was told time and time again by those who frequent, work in and help administer the centre, 'it's like a home'.

Paolo Boccagni (2017) argues that, for a place to become home-like, a sense of familiarity, security and control (over one's life environments) must emerge from one's interactions with it. In comparing Al-Nur to a home, my interlocutors especially alluded to familiarity and security, emphasising the physical and emotional comfort that they felt when spending time at the centre and the relationships they formed with other members of the centre.

Safouan, a Syrian in his early 20s, was one of the five in the training programme aiming at acceptance to a US or Canadian university. In exchange for 
his participation in the programme, he helped with the management of $\mathrm{Al}$ Nur. In his view, 'NGO' was a misnomer for Al-Nur because NGOs are more formal, revolving around reports, numbers and statistics, whereas Al-Nur was like 'a home'. It had a kitchen and comfortable areas in which to sleep or take a nap. It was relatively accessible to anyone. With every new person who came, there was an opportunity for friendship.

Marwan, a Syrian Kurd in his early 20s, was also in the university scholarship programme. For him, Al-Nur was not your typical NGO: it was 'a club, a home'. As a Kurd, he had experienced 'racism' in Turkey from both Turks and Syrian Arab refugees. One aspect of the centre that felt like home to him was what he described as its lack of racism and its openness to diversity, whether ethnic, religious or ideological. The core adherents tend to be secular and socially liberal, with a few self-proclaimed Marxists, but, as Marwan pointed out, Al-Nur does also include practising Muslims. Marwan also compared the structure of the centre to that of a family. He saw his opportunity to continue his studies in Canada as a result of Khaled having taken on the role of a father who, just as his own father had attempted to when Syria descended into instability, was helping him pursue higher education abroad. While Marwan did have some relatives in Turkey, I noticed that many of the refugees from Syria who frequented the centre on a regular basis (mostly young men but also some women) had been separated from their biological family in the process of migrating to Istanbul. In that sense, the centre as a whole can be seen as a substitute family for some of its regular members and clients.

Cathy, an American, is one of two non-Syrian women working in Al-Nur's administration. She initially got involved with the centre by teaching art classes, but now helps run it. During our interview, she did not explicitly emphasise the themes of home and family in the way that other interviewees had, but she certainly felt that Al-Nur was different from a typical NGO. According to her, Al-Nur was unique in its vision and the way it operated: 'It's Syrian-run ... it's not a bunch of foreigners handing out things to refugees and ... it's not a charity, you know; it's a community centre ... so the needs and the dignity and the respect for Syrians comes first, before the need for PR or fundraising. She contrasted Al-Nur with other, bigger NGOs assisting refugees in Istanbul through the following example. Al-Nur, attracted by the prospect of access to more money and resources, had agreed to partner with a larger international NGO. However, the partnership fell apart within months because of its drastic effect on Al-Nur's intimate and home-like atmosphere. Suddenly, refugees taking classes at the centre had to sign their names on sign-up sheets, and specific sums of money were allocated for specific resources or goals and had to be spent by a specific time, whether or not resources were needed. The larger international NGO also encouraged Al-Nur to promote itself in media outlets as a means of fundraising, which meant that it had to accommodate journalists who wanted to take pictures of refugees using the centre. Khaled and Cathy eventually concluded that these practices were destroying the intimate, cozy 
atmosphere they were trying to create at Al-Nur and that they were dehumanising to the refugees who frequented the centre by tracking their attendance and turning them into objects of display for the media.

As others have argued, homemaking cannot be reduced to simply recreating aspects of one's former home in exile, to a nostalgic way of clinging to a former life that is out of reach; it is also very much about the ability to move on with one's life in exile and to make the best of one's surroundings. Anthropologist Ghassan Hage points out that attempts to (re)create aspects of one's former home while in exile should be seen as 'affective building blocks migrants use to make themselves feel at home where they actually are. They are part of the migrant's settlement strategies rather than an attempt to escape the realities of the host country' (2010: 419). Hart et al. (2018) show in their work that efforts by Syrian refugees in Jordanian camps to turn their shelters into homes should not be read in a dichotomous manner that equates shelter with temporariness and home with settlement in the space of residence. Rather, 'the desire to return to a former place of residence co-exists with the effort to enhance one's immediate surroundings' (2018: 374). This mutuality was present at Al-Nur, which strove to be both a home similar to the ones refugees had left behind in Syria and a place where refugees could take classes that helped them establish productive lives in Turkey and beyond.

Al-Nur's attempt to both recreate aspects of home associated with life in Syria and encourage refugees to build a successful future for themselves while in exile exceeds the centre's emphasis on Turkish and English language classes and its small study-abroad scholarship programme. It is encapsulated in the example of Fatma, a single mother in her 40s from the Syrian city of Homs. At the time of my fieldwork, she was responsible for most of the cooking and for keeping the centre clean. Unlike other staff, she received a modest salary, which helped her to pay rent and buy basic necessities. She had completed a journalism degree in Syria shortly before the war but fled to Turkey in 2014 primarily to protect her only son, Younes, from the war and from conscription into military service.

During our interview, Fatma told me that, though she was paid for her work at Al-Nur, she did not feel like an employee. 'I don't consider it work, it's my house; the house where I [pay rent], I only sleep there and wash my clothes. I stopped cooking [there] after my son travelled'. Fatma's son had, through Al-Nur and the American NGO it was partnered with, received a scholarship to finish high school in the United States. At Al-Nur, she not only cooked and cleaned but took Turkish, English, French and theatre classes and regularly attended the Friday movie night: 'My life is completely intertwined with Al-Nur; when I return home, I don't do anything.' Also, after three years in Turkey her career as an aspiring journalist was finally moving forward. A few days before I interviewed her, in April 2017, her first article was published in a Turkey-based Syrian online newspaper. 
During the three months that I volunteered at Al-Nur, I encountered only one Palestinian Syrian, other than Khaled, amongst the refugees frequenting the centre. On the very first day that I went to Al-Nur, in early February, I met Talal, who was in his late 50s and who had spent most of his life in Syria's Yarmouk camp. ${ }^{7}$ He was seated in the centre's common area adjoining the kitchen with a few of the centre's regular staff. Talal introduced himself to me as a 'book thief'. He estimated that, as a teenager growing up in Syria's Yarmouk camp, he probably stole close to 1,000 books from various bookstores and libraries in Damascus. Growing up in 'a poor environment', he and the friends who joined him legitimised such conduct by reasoning that books are a source of knowledge that should be accessible to all, including those who cannot afford them. 'We realised [stealing books] was wrong when we grew up. Overall though, he does not regret this period in his life, especially because some of the books he stole had been sent to Syria as part of Soviet propaganda and should have been affordable but were sold at expensive prices by bookstore owners seeking to maximise their profits. By the time he was 21, Talal knew more about Russian literature than Palestinian or Arab literature in general: 'I used to love the poems by (Vladimir) Mayakovski, the poems of the Russian Revolution ... I knew him even before I knew Mahmoud Darwish, Nizar Qabbani and Mudhaffar Al-Nawab'. Talal would grow up to be a successful journalist who could afford to buy his own books, acquiring a collection of about 6,000 volumes. On the day I met him, he showed me a picture of his personal library, extending along every single wall of his apartment in Yarmouk. 'I don't care about the house, any of it. I just want my books back. They were like friends to me', he said during our interview on a cold February day in 2017.

Talal's comment encourages us to think about homemaking not only in terms of the human interactions linked to a particular space, but also in terms of the interactions between humans and the artefacts that populate that space. Like many other Palestinian inhabitants of Yarmouk, Talal fled the camp in December 2012 after it was hit by aerial bombings from the Syrian military that destroyed a mosque, four schools and a hospital and that killed at least 25 civilians, many of them internally displaced Syrians who had been sheltering in some of those buildings (see Amnesty International 2014). He moved to a town on the outskirts of Damascus, but ultimately decided to leave Syria to escape what he described as 'a daily life of constant fear and terror'. During our interview, he most vividly remembered the fear of arrest, or worse, that he felt every time he crossed a military checkpoint and the terror caused by the cycles of bombings in nearby Damascus. The lack of water, heat and electricity and the rising prices were additional factors. With the assistance of smugglers, he made it to Erbil in Iraq and then to Turkey in January 2017. While awaiting further instructions from smugglers with regard to his goal of reaching Europe, he was renting a hotel room in Istanbul and frequenting Al-Nur on a daily basis mostly to mingle with others. 
Similar to a significant number of Palestinian refugees from Syria whom I interviewed in the aftermath of the Syrian War, the sudden and unexpected descent into violence and instability in Syria - one of the Middle Eastern countries that had been the most welcoming to them - and the difficulties they had faced trying to find safety, convinced him of the importance of obtaining a passport, preferably a Western one, given the hierarchies that govern global freedom of movement. He had wanted to leave Syria as early as 2012, when he was displaced from Yarmouk, but had wanted to do this 'legally'. In particular, Talal was hoping to make it to Norway because, according to him, one could get citizenship there within the relatively short period of three years. However, after unsuccessfully applying for visas at all of the European embassies and consulates he had access to, Talal finally resorted in 2017 to enlisting the help of smugglers. It turned out to be a dehumanising experience in terms of the physical impact of the journey and in terms of his treatment by the smugglers, who were verbally abusive and who took advantage of the difficult route to Turkey to extort additional money from him.

After spending about six weeks in Istanbul, Talal decided that his quest to reach Europe clandestinely was taking too much of a physical and psychological toll on him. He planned to return to Syria: 'I came here to go to Europe, but there's no smuggling now. The sea is high and rough and there're no smugglers. Also, life in Istanbul is expensive; staying here means spending a lot of money. Here I am waiting. I don't know where I will get. But one has dignity, so I fear reaching a point where I become needy, [in which case] I'd prefer to go back to where I came from'. At least in Syria, Talal had a roof over his head, his siblings and the minimum to survive on a day-by-day basis without depending on outside help. In mid February 2017, a few days after I last saw him in Istanbul, I received a text message from Talal informing me that he had returned to Syria.

\section{Recurring Displacements, Homemaking and Refugee-Refugee Solidarity}

The story of Al-Nur - and those who manage it, work in it or, like Talal, frequent it - offers several insights into how refugees cope with forced displacement and the kinds of support mechanisms they rely on while living in exile. First of all, refugees, whether camp-based or not, need support mechanisms that will enable them to achieve stability, economic security and a 'normal' life in their host country. As shown in this article, some of these mechanisms are best provided by refugees themselves. Additionally, the ability to recreate a sense of home in one's place of exile is an important source of emotional and psychological support that contributes to refugee efforts to adjust to their new environment and to begin to build a future for themselves in this environment.

While homemaking has many dimensions and varies according to social and cultural contexts, the consumption of food can be an important aspect 
of it (Hage 2010; Hart et al. 2018; Vandevoordt 2017). As mentioned by others, Syrians are widely noted for their culinary skills, and food has played an important social role in Syrian refugee communities (Hart et al. 2018; Vandevoordt 2017). For example, for a number of Syrian refugees in camps in Jordan, improving their shelters means transforming them into 'homes' by creating spaces that are amenable to the culture of hospitality they enjoyed in Syria and which entails certain eating and hosting rituals (Hart et al. 2018). Similarly, sociologist Robin Vandervoordt notes that for Syrian refugees in a camp in Belgium, acting as hosts and providing Syrian cuisine to guests within these spaces demonstrates both a positive assertion of Syrian identity and a reversal of the power hierarchies that constrain their freedom of movement and self-expression within the camp (Vandevoordt 2017).

The above examples extend to Palestinian Syrians. A major theme across the interviews that I conducted with Palestinians displaced to Europe by the Syrian war was the hardship endured during the journey to Europe and during their stay in initial reception centres across Europe as a result of not being able to cook or eat food that was familiar to them. More specifically, Vandevoordt's experience with Syrians living in a refugee camp in Belgium brings to mind my own experience with a Palestinian Syrian family consisting of a mother, her daughter, and her future daughter-in-law, who were living in Berlin's Tempelhof airport-turned-camp in summer 2016. Similar to Vandevoordt's example, refugees in Tempelhof were not allowed to bring food into the camp and were forced to eat the meals provided at specific hours by the camp's management. They also were not allowed to bring guests into the camp. This, however, did not prevent the family from hosting me every time we met on the lawn facing the Tempelhof hangars that had been turned into Germany's largest refugee camp in the wake of the Syrian refugee crisis. The women would bring out their shisha pipe, which was passed around while we enjoyed coffee and sunflower seeds (bidhar) on the grass, recreating an atmosphere familiar to anyone who has spent time in Syria. The sense of familiarity emanated not just from the items we were consuming, but also from the fact that public lawns are major spaces of socialisation for individuals and families in Syria.

It is perhaps not a coincidence that Khaled has been particularly successful in turning Al-Nur into a 'home' for himself and those who frequent it. As scholars have noted, despite the hardships and history of dispossession associated with their camps, and parallel to vibrant and ongoing advocacy for the right of return to their Palestinian homeland, Palestinian refugees have been able to transform their camps into meaningful places, into 'homes' (Gabiam 2016; Peteet 2005). Yarmouk's particularities as an urban camp undoubtedly influenced Khaled's approach to homemaking and to the creation of Al-Nur as a centre catering to both Syrians and Palestinian Syrians. Before the war, Yarmouk had become an urban space that was well-integrated into Damascus and had a large number of Syrian residents. It was a space where Syrians and Palestinian Syrians lived in proximity to each other and routinely interacted 
with one another. In the early days of the Syrian War, before the December 2012 bombings that fully drew the camp into the war, Yarmouk had also been a refuge for internally displaced Syrians. Many of the Palestinian Syrians from Yarmouk whom I interviewed took special pride in the fact that Palestinian residents and social organisations in the camp had mobilised to host displaced Syrians, providing them with shelter, food and medical assistance in the early days of the war.

At the same time, Yarmouk was a deeply Palestinian space in terms of the political activism of its Palestinian residents, their strong sense of Palestinian identity and the extent to which they had imbued the space of the camp with symbols and imagery relating to their Palestinian history and to the Palestinian cause (Gabiam 2016). Yarmouk was often described as a substitute or placeholder for the Palestinian homeland in the interviews I conducted with Palestinians who are now displaced from there. It was a space that was quintessentially Palestinian, yet highly integrated into the Syrian social fabric. Khaled not only grew up and lived in such a space until the Syrian War, but took particular pleasure in turning his house in Yarmouk into a space of hospitality where he regularly hosted and cooked for a diverse group that included not just camp residents but outsiders as well (amongst them foreigners such as myself). Al-Nur emerged out of his efforts to recreate this homemaking experience, one that can be considered at once Palestinian, Syrian and cosmopolitan, while in exile in Turkey. Additionally, it makes sense that Al-Nur is a space where other minorities displaced from Syria (such as Syrian Kurds) feel at home. Ultimately, what the centre's management and clients had in common was, rather than a specific ethnic identity, their displacement from Syria and the desire to feel at home in exile.

As noted by Elena Fiddian-Qasmiyeh (2016), refugee-refugee solidarity, having long been glossed over by scholars, should be highlighted but not romanticised. My focus on Al-Nur is not meant to romanticise inter-ethnic relations amongst the displaced from Syria, nor refugee-refugee solidarity nor the homemaking capacities of Palestinian refugees, for that matter. Rather, the example of Al-Nur points to the multiple scales at which homemaking happens and which include the personal, social and national realms, realms that can overlap (see Boccagni 2017). The fact that Al-Nur caters to an ethnically diverse population of refugees from Syria is not strange, but it is also not representative of an all-encompassing Syrian reality transplanted into Turkey. For example, Syrian Kurds have long faced marginalisation and discrimination on the part of Syrian authorities (Noi 2012). As Marwan noted above, Kurds in the Middle East are susceptible to discrimination from members of non-Kurdish majority groups such as Arabs and ethnic Turks (within Turkey). Finally, not all Palestinian refugee camps in pre-war Syria were as integrated into Syrian society as Yarmouk was. Some, such as Neirab and Ein el Tal in northern Syria, where I conducted fieldwork before the Syrian War, were more homogeneously Palestinian than Yarmouk and more socially and physically 
isolated from their surroundings. About two hundred Palestinian families displaced from those camps congregated in the Turkish border town of Kilis, forming the one community of Palestinian Syrians I encountered during my fieldwork. I met some of these families, who lived in close proximity to one another in a series of adjoining apartment buildings while I was conducting fieldwork in Kilis in 2015. The sense I got from my interviews and conversations with them at the time was that they felt excluded from general Turkish assistance to refugees from Syria. Many of these families have since migrated to Europe.

\section{Conclusion}

At Al-Nur, homemaking takes precedence over all of its other functions. Symbolic prestige tied to media attention, the capacity to attract funding and the capacity to cooperate with larger NGOs and maximise resources, features that drive competition amongst NGOs (see Daniş and Nazli 2018; Sunata and Tosun 2018), are shunned. To the extent that funding is needed, it comes primarily from individual donors who do not determine the centre's planning and programming. Al-Nur is a place where volunteers come and go, where the vast majority of classes, activities and opportunities depend on who is there and what they have to offer. The study abroad training programme, which can last up to three years, only caters to four or five refugees from Syria at a time, a tiny minority of the centre's clientele. What is constant are the centre's efforts to make refugees from Syria feel at home. The philosophy that guides Al-Nur is very much influenced by Khaled's own personal experience as a doubly displaced refugee from the Yarmouk camp, an urban space that, before the Syrian War, was characterised by a strong sense of Palestinian identity as well as a high level of socio-economic integration into Syrian society.

While Khaled was able to create a sense of home for himself and others in Istanbul, the current reality for Palestinian refugees is that homemaking in the Middle East is becoming an increasingly precarious and unstable endeavor, one that is marked by repeated crises, displacements and hostile government policies specifically targeting Palestinians. Since the 1948 Nakba (Catastrophe), Palestinian forced displacement has continued as a result of subsequent Arab-Israeli and Palestinian-Israeli conflicts, other conflicts in the Middle East and state policies specifically directed at Palestinians - for example, the expulsion of Palestinians from Kuwait in the aftermath of the First Gulf War and from Libya after the signing of the 1994 Oslo Accords, and ongoing Israeli policies of settlement, house demolition and land confiscation in the Occupied Territories.

Recurrent Palestinian displacement, especially in the wake of the Syrian War, has led an increasing number of Palestinians to conclude that homemaking in the Middle East is currently not a viable option and to continue 
on to Europe. However, as exemplified by Talal, who ultimately returned to Syria, reaching Europe is not an easy endeavor. The difficulties he faced take us beyond the realm of Palestinian exceptionalism. Even if Palestinian Syrians have faced additional hurdles due to their Palestinian identity, pre-existing refugee status, and statelessness in their quest to find protection from war, Talal's experience is also indicative of a broader global trend characterised by the increasing tightening of borders against migrants, including refugees, trying to reach the Global North (see Kingsley 2017). When Talal finally decided to seek asylum in Europe in 2017, Turkey had built a wall on most of its border with Syria and signed an agreement with the European Union that required Turkey to crack down on migrants on its territory seeking to take the irregular route to Europe. Additionally, because the irregular journey from the Middle East to Europe has become much more arduous, it has also become much more expensive for the migrants considering it.

By drawing on the concepts of home and homemaking, the above analysis captures the nuances and complexities of what has come to be known as 'the Syrian refugee crisis. This analysis has shown that Palestinian Syrians are very much a part of Syria's refugee crisis and that they have much in common with displaced Syrian nationals. However, it has also highlighted important differences in the experiences of exile of the two groups, differences that are linked to the specific histories of Palestinian displacement in the Middle East and the specific policies that displaced Palestinian Syrians have faced on the part of host states by virtue of their Palestinian identity, prior refugee status and statelessness. Finally, this analysis has shown that focussing on the experiences of displaced Syrians and Palestinian Syrians within a particular location, Turkey, should not blind us to the ways in which these experiences are shaped by larger global forces impacting the majority of refugees in the twenty-first century.

Nell Gabiam is Associate Professor of Anthropology and Political Science and Co-Director of the Middle Eastern Studies Minor Programme at Iowa State University. She received her $\mathrm{PhD}$ in anthropology from the University of California-Berkeley in 2008. She is the author of The Politics of Suffering: Syria's Palestinian Refugee Camps (Indiana University Press 2016). She is currently working on her second book, which is the result of fieldwork conducted primarily in Lebanon, Turkey, France, Germany and Sweden. The book examines how mass displacement from Syria as a result of the ongoing war in that country has affected Palestinian identity and political claims. Email:ngabiam@iastate.edu 


\section{Notes}

1. I designate Palestinians who were already refugees in Syria and have now been displaced by the Syrian War to Turkey as 'Palestinian Syrians' because this is a terminology that came up frequently during my fieldwork as a form of identification by Palestinian interlocutors and because this is the term used by the Al-Nur community centre, which is the ethnographic focus of this article.

2. I have changed the name of the centre to protect its identity.

3. As Ahmet Içduygu and Evin Millet (2016) point out, this identity document is not a residency permit and does not enable the holder to apply for permanent residency or citizenship in Turkey.

4. As of 2016, Syrian nationals also require a visa in order to enter Turkey.

5. And from interviews with Palestinian refugees in Turkey, Spring 2015.

6. I have changed the interviewees' names in order to protect their identities.

7. Talal, who was just passing through Istanbul, was an exception to the rule of not interviewing the centre's clientele.

\section{References}

AGPS (Action Group for the Palestinians of Syria) and PRC (Palestinian Return Centre) (2018), Palestinians of Syria: Life Under Restrictions: Annual Field Report of the Situation of the Palestinians of Syria in 2017, AGPS and PRC, https://prc.org. uk/en/post/3991/palestinians-of-syria-life-under-restrictions (accessed 13 January 2021).

Amnesty International (2014), Squeezing the Life out of Yarmouk: War Crimes against Besieged Civilians, Amnesty International, 10 March, http://www. amnestyusa.org/research/reports/syria-squeezing-the-life-out-of-yarmouk-warcrimes-against-besieged-civilians.

Boccagni, P. (2017), Migration and the Search for Home: Mapping Domestic Space in Migrants' Everyday Lives (London: Palgrave Macmillan).

Clementi, A. (2015), 'No Way Out: The Second Nakba of Refugees from Syria Escaping to Turkey', Al Majdal 57, https://www.badil.org/en/publication/periodicals/al-majdal/ item/2079-article-9.html.

Daniş, D. and Nazli, D. (2018), 'A Faithful Alliance between Civil Society and the State: Actors and Mechanisms of Accommodating Syrian Refugees in Istanbul', International Migration 57 no. 2: 143-157, doi:10.1111/imig/12495.

Fiddian-Qasmiyeh, E. (2016), 'Refugees Hosting Refugees', Forced Migration Review 53: 25-27, https://www.fmreview.org/community-protection/fiddianqasmiyeh (accessed 13 January 2021).

Gabiam, N. (2016), The Politics of Suffering: Syria's Palestinian Refugee Camps (Bloomington: Indiana University Press).

Hage, G. (2010), 'Migration, Food, Memory, and Home-Building', in Memory: Histories, Theories, Debates, (ed.) S. Radstone and B. Schwarz (New York: Fordham University Press), 416-427. 
Hart, J., Paszkiewicz, N. and Albadra, D. (2018), 'Shelter as Home? Syrian Homemaking in Jordanian Refugee Camps', Human Organizations 77, no. 4: 371-380, doi:10.17730/0018-7259.77.4.371.

Içduygu, A. (2016), 'Syrian Refugees in Turkey: The Long Road Ahead', Migration Policy Institute, Transatlantic Council on Migration, http://www.migrationpolicy. org/research/syrian-refugees-turkey-long-road-ahead (accessed 13 January 2021).

Içduygu, A. and Millet, E. (2016), 'Syrian Refugees in Turkey: Insecure Lives in an Environment of Pseudo-Integration', Working Paper 13. Istanbul Policy Centre, Koç University, Istanbul, http://www.iai.it/sites/default/files/gte_wp_13.pdf.

Içduygu, A. and Sert, D. (2019), 'Introduction: Syrian Refugees - Facing Challenges, Making Choices', International Migration 57, no. 2: 121-125, doi:10.1111/imig.12563.

Içduygu, A., Üstübici, A., Aral, I. and Ayar, B. (2017), 'Legitimising Settlement of Refugees: Unpacking Humanitarianism from a Comparative Perspective', Geografie 122, no. 4: 449-475, doi:10.37040/geografie2017122040449.

Kingsley, P. (2017), The New Odyssey: The Story of the 21st Century Refugee Crisis (New York: Liveright).

Kirişci, K. and Ferris, E. (2015), Not Likely to Go Home: Syrian Refugees and the Challenges to Turkey - and the International Community, Brookings Institute, Policy Paper no. 7, September, https://www.brookings.edu/research/not-likely-to-go-home-syrianrefugees-and-the-challenges-to-turkey-and-the-international-community/.

Leghtas, I. (2019), Insecure Future: Deportation and Lack of Legal Work for Refugees in Turkey, Refugees International, 18 September, https://www.refugeesinternational. org/reports/2019/9/18/insecure-future-deportations-and-lack-of-legal-work-forrefugees-in-turkey.

Noi, A. Ü. (2012), 'The Arab Spring, Its Effects on the Kurds, and the Approaches of Turkey, Iran, Syria, and Iraq on the Kurdish Issue', Middle East Review of International Affairs 16, no. 2: 15-29, doi:10.1057/9781137445551_6.

Peteet, J. (2005), Landscapes of Hope and Despair: Palestinian Refugee Camps (Philadelphia: University of Pennsylvania Press).

Sunata, U. and Tosun, S. (2018), 'Assessing Civil Society's Role in Refugee Integration in Turkey: NGO-R as a New Typology', Journal of Refugee Studies 32, no. 4: 683-703, doi:10.1093/jrs/fey047.

UNHCR (United Nations High Commissioner for Refugees) (2015), The Sea Route to Europe: The Mediterranean Passage in the Age of Refugees, UNHCR, 1 July, https://www.unhcr.org/en-us/protection/operations/5592bd059/sea-route-europemediterranean-passage-age-refugees.html.

UNHCR (2020), 'Syrian Regional Refugee Response', https://data2.unhcr.org/en/ situations/syria/location/113 (accessed 13 January 2021).

Vandevoordt, R. (2017), 'The Politics of Food and Hospitality: How Syrian Refugees in Belgium Create Home in Hostile Environments', Journal of Refugee Studies 30, no. 4: 605-621, doi:10.1093/jrs/fex017.

Yahia, W. K. (2020), 'Bada al ya’as min aljihat alfilastiniya alrasmiya filastiniu suriya fi turkiya yahiluna mashakilahum alqanuniya bi'anfusihim' [After giving up on formal Palestinian entities, Syria’s Palestinians solve their problems by themselves], Palestinian Refugee Portal, https://refugeesps.net/posts/14103 (accessed 13 January 2021). 